\title{
REVIEW
}

\section{Cyclic AMP and progesterone receptor cross-talk in human endometrium: a decidualizing affair}

\author{
B Gellersen and J Brosens ${ }^{1}$ \\ IHF Institute for Hormone and Fertility Research, University of Hamburg, Hamburg, Germany \\ ${ }^{1}$ Institute of Reproductive and Developmental Biology, Wolfson and Weston Research Centre for Family Health, Imperial College London, \\ Hammersmith Campus, London W12 0NN, UK \\ (Requests for offprints should be addressed to J Brosens; Email: j.brosens@ic.ac.uk) \\ (B Gellersen is currently at Endokrinologikum Hamburg 20251 Hamburg, Germany)
}

\begin{abstract}
During the menstrual cycle, the ovarian hormones oestradiol and progesterone control the ordered growth and differentiation of uterine cells. This remodelling process is critical for implantation of the developing embryo, the formation of the placenta, and maintenance of pregnancy. Failure of uterine tissues to respond appropriately to ovarian hormone signalling results in defective placentation, associated with a spectrum of pregnancy disorders such as recurrent miscarriages and preeclampsia. These obstetrical disorders are a major cause of maternal and perinatal morbidity and mortality. Progesterone exerts its action on target cells, at least in part, through binding to the progesterone receptor (PR), a member of the steroid/
\end{abstract}

thyroid hormone receptor superfamily of ligand-activated transcription factors. The mechanism by which progesterone controls the differentiation of human endometrial stromal cells, a process termed decidualization, in the secretory phase of the menstrual cycle is not well understood. Emerging evidence indicates that locally expressed factors and activation of the cAMP second messenger pathway integrate hormonal inputs and confer cellular specificity to progesterone action through the induction of diverse transcription factors capable of modulating PR function.

Journal of Endocrinology (2003) 178, 357-372

\section{Introduction}

The postovulatory rise in ovarian progesterone induces profound remodelling of the oestrogen-primed endometrium, characterized initially by growth and coiling of the spiral arteries, secretory transformation of the glands, influx of distinct immune cells, and subsequently by decidualization of the stromal compartment. Decidualization represents a process of morphological and biochemical differentiation (Fig. 1). The decidualized endometrial stromal cell (ESC) becomes rounded, acquires myofibroblast characteristics, and secretes a variety of phenotypic antigens, including prolactin (PRL), insulin-like growth factor binding protein-1 (IGFBP-1) and tissue factor (TF) (Daly et al. 1983, Irwin et al. 1989, Tabanelli et al. 1992, Tseng et al. 1992, Lockwood et al. 1993, Gellersen et al. 1994, Oliver et al. 1999b, Christian et al. 2001b). At a molecular level, decidual transformation involves extensive reprogramming of many cell functions including altered steroid hormone receptor expression and steroid metabolism, remodelling of the extracellular matrix and cytoskeleton, altered expression of intracellular enzymes, growth factors and cytokines and their receptors, and induction of apoptosis modulators and decidua-specific transcription factors (Oliver et al. 1999a, Popovici et al. 2000, Brar et al. 2001).

The term 'decidualization' is derived from the Latin verb 'decidere' which means to 'fall off'. In the 19th century, Thomas Huxley suggested that the order Mammalia should be subdivided into 'Deciduata' and 'Adeciduata', depending on whether the uterine mucosa is cast off at parturition. In contrast to many species, decidualization of the endometrial stroma in humans is independent of the presence of an implanting blastocyst. However, in the absence of conception, falling circulating progesterone levels in the late secretory phase of the cycle elicit sloughing of the decidualized superficial endometrial layer and menstruation. In pregnancy, the decidual reaction extends to the basal endometrial layer and is critical for trophoblast invasion and placenta formation (Brosens et al. 

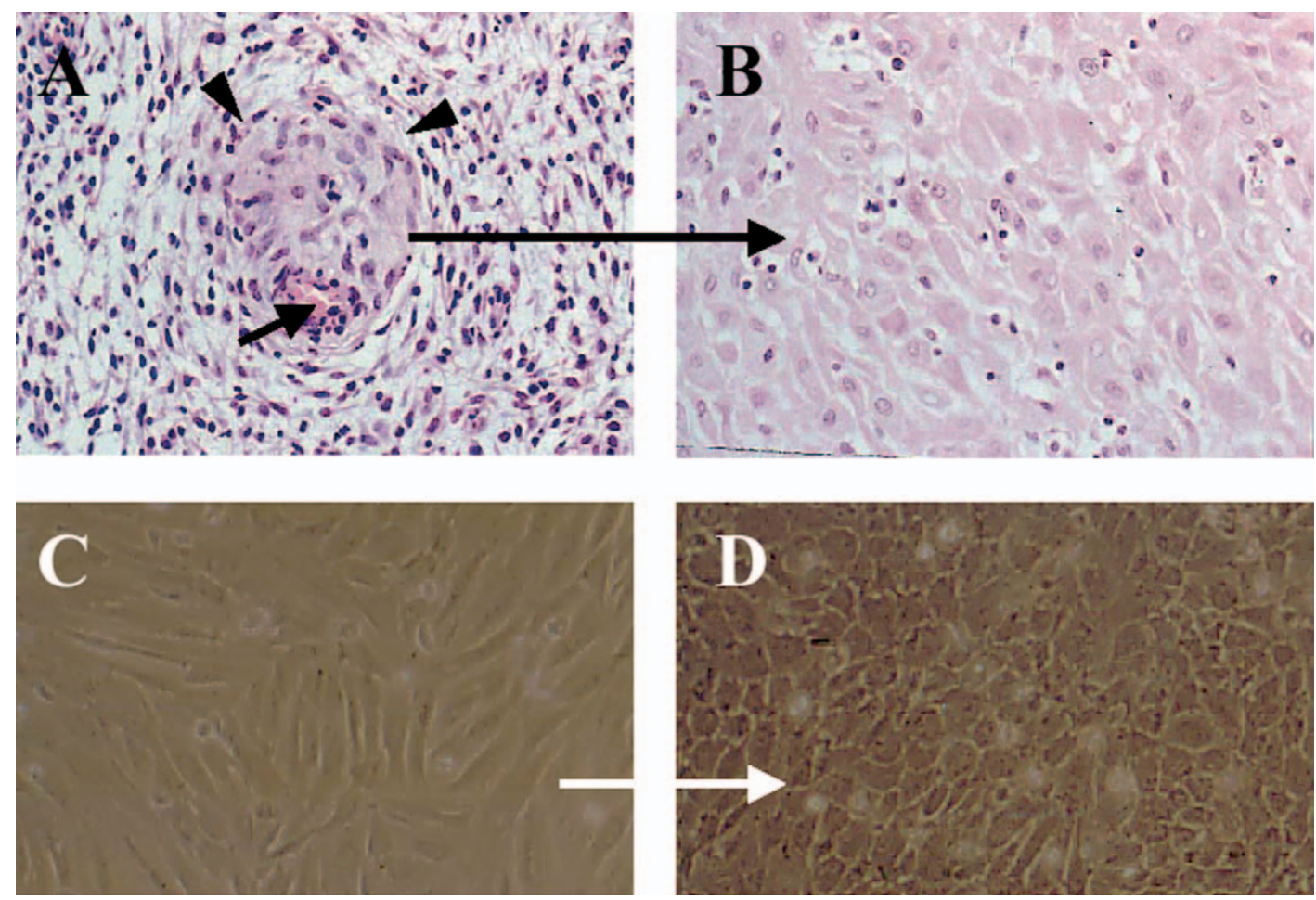

Figure 1 Decidual transformation of endometrial stromal cells (ESC) in vivo and in vitro. (A) Initiation of the decidual response in stromal cells (arrow heads) on day 23 of the cycle around the terminal portion of a spiral artery (arrow). (B) Extensive decidual transformation of the stromal compartment of the superficial endometrium in the late luteal phase of the cycle. (C) Undifferentiated primary ESC display a fibroblastic spindle-shaped morphology. (D) Treatment of confluent monolayers with 8-bromo-cAMP, alone or in combination with a progestin, for $48 \mathrm{~h}$ transforms the spindle-shaped cells into cells with larger nuclei and abundant cytoplasm, resembling decidual cells.

2002). Indeed, decidualization only occurs in species in which placentation involves breaching of the luminal epithelium by the trophoblast and the extent of this differentiation process often correlates with the degree of trophoblast invasion (Ramsey et al. 1976, Brosens et al. 2002). Furthermore, various mouse knock-out models have provided unequivocal proof that endometrial decidualization is essential for maintaining pregnancy (Table 1). Implantation and early pregnancy are further characterized by profound vascular changes and influx of uterine natural killer cells and macrophages (King 2000, Brosens et al. 2002). Hence, it appears likely that the decidual reaction per se is important to protect endometrial cells against inflammatory signals and oxidative stress.

There is abundant clinical and experimental evidence in support of a critical role of progesterone in maintaining the decidual phenotype. However, decidual transformation is first apparent in stromal cells surrounding the spiral arteries approximately ten days after the postovulatory rise in ovarian progesterone levels (de Ziegler et al. 1998), indicating that the expression of decidua-specific genes is unlikely to be under direct transcriptional control of activated progesterone receptor (PR). Furthermore, progesterone is a very weak inducer of the decidual pheno-
Table 1 Knock-out mice with impaired decidual reaction

\section{Reference}

\section{Disrupted gene}

COX-2

Leukaemia inhibitory factor

Progesterone receptor

PR-A

Steroid receptor coactivator-1

Hoxa-11

Hoxa-10

IL-11 receptor

Components of IFN- $\gamma$ signalling
Lim et al. (1997)

Stewart \& Cullinan (1997)

Lydon et al. (1995)

Mulac-Jericevic et al. (2000)

Xu et al. (1998)

Gendron et al. (1997)

Ma et al. (1998)

Bilinski et al. (1998),

Robb et al. (1998)

Ashkar et al. (2000) type in cultured purified primary ESC (Fig. 2). Evidence has emerged to suggest that initiation of the decidual process requires elevated intracellular cAMP levels and sustained activation of the protein kinase A (PKA) pathway. This commentary focuses on the intricacies of cAMP and PR signalling and cross-talk in human ESC which hitherto have escaped recognition in model cell lines. 


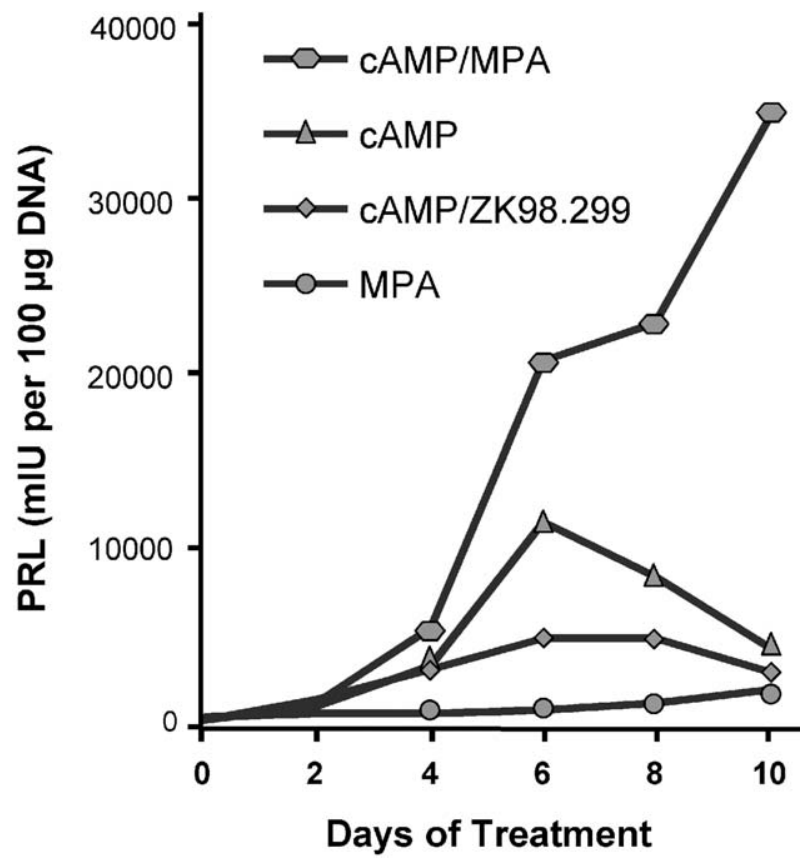

Figure 2 PRL production by primary ESC in response to CAMP, progestins and antiprogestins. Confluent ESC were treated with 8-bromo-cAMP (cAMP; $0.5 \mathrm{mM})$, the progestin MPA $\left(10^{-6} \mathrm{M}\right)$, the pure antiprogestin ZK98.299 $\left(10^{-6} \mathrm{M}\right)$, or a combination of these as indicated. The medium was changed every $48 \mathrm{~h}$. The data represent the mean of PRL concentrations in the supernatant, normalized for DNA content in each well at a given time point.

\section{Biochemical mechanism of decidualization: role of cyclic AMP}

Cyclic AMP signal transduction - an overview

Cyclic AMP is a ubiquitous second messenger molecule which is generated upon binding of a ligand to members of a receptor family which are classified by seven transmembrane-spanning domains. These receptors are coupled to the heterotrimeric guanine nucleotide-binding proteins (G-proteins) and are hence designated G-proteincoupled receptors (GPCR). Upon ligand binding, the $G \alpha$ subunit is released from the trimeric $G \alpha \beta \gamma$ complex and regulates the activity of adenylyl cyclase, an enzyme which produces cAMP from ATP (Dessauer et al. 1996). A major downstream recipient of cAMP is the cAMP-dependent PKA, a cytoplasmic enzyme which in its basal state is composed of two regulatory and two catalytic subunits (Skålhegg \& Taskén 2000). Upon binding of two cAMP molecules to each regulatory subunit, the latter undergo a conformational change which results in release and activation of the catalytic subunits. These may phosphorylate target molecules in the cytoplasm or diffuse into the nucleus and modulate the activity of transcription factors by phosphorylation. Major nuclear targets of PKA phosphorylation are the cAMP response element binding protein (CREB) and the related cAMP response element modulator (CREM) (Mayr \& Montminy 2001). CREB and CREM belong to the family of basic region/leucine zipper (bZIP) transcriptional regulators which dimerize through the leucine zipper and bind to their cognate DNA sequence through the basic region (Luscombe et al. 2000). The optimal binding site for CREB and CREM is the palindromic cAMP response element (CRE) TGACGTCA. Phosphorylated CREB/CREM recruits the co-activator CREB binding protein $(\mathrm{CBP})$ to the promoter region of their target genes. CBP, owing to its inherent histone acetyltransferase activity, facilitates transcription by modulation of chromatin conformation (Ogryzko et al. 1996, Montminy 1997, Mayr \& Montminy 2001).

\section{Cyclic AMP signal transduction in differentiating human endometrium}

Cyclic AMP signalling in general is controlled at many levels. These include regulation at the receptor level, catabolism of cAMP by phosphodiesterases, modified composition of the PKA holoenzyme, expression of CREB and CREM isoforms with altered transcriptional activity, or a change in the expression level of coactivators or corepressors. Ultimately, in most cell systems, these mechanisms are aimed at terminating cellular responses to a lasting external stimulus. Human endometrial stromal cells represent an exception to this rule in that they are dependent on a persistent stimulation of the cAMP pathway to acquire and maintain the decidualized phenotype (Tanaka et al. 1993, Telgmann \& Gellersen 1998). Upon withdrawal of the cAMP stimulus, decidualized ESCs re-acquire an undifferentiated phenotype and cease to express differentiation markers such as PRL and IGFBP-1 (authors' unpublished observations).

G-protein-coupled receptors Peptide hormones and prostanoids implicated in promoting the decidual transformation include the gonadotrophins luteinizing hormone/ human chorionic gonadotrophin (LH/hCG), corticotrophin releasing hormone $(\mathrm{CRH})$, relaxin (RLX), and prostaglandin $\mathrm{E}_{2}\left(\mathrm{PGE}_{2}\right)$ (Tseng et al. 1992, Tang \& Gurpide 1993, Frank et al. 1994, Ferrari et al. 1995). These molecules share the ability to provoke an increase in intracellular cAMP levels by binding to GPCR coupled to the stimulatory Gs $\alpha$ protein (Gilchrist et al. 1996, Herrlich et al. 1996, Gravanis et al. 1999, Narumiya et al. 1999, Breyer et al. 2001, Narumiya \& FitzGerald 2001, Hillhouse \& Grammatopoulos 2002, Hsu et al. 2002, Sudo et al. 2002). While the presence of gonadotrophin receptors on cultured ESC has been demonstrated (Han et al. 1997), the decidualizing potential of LH/hCG is still a matter of debate (Tang \& Gurpide 1993, Kasahara et al. 2001). The $\mathrm{PGE}_{2}$ receptor subtypes $\mathrm{EP}_{2}$ and $\mathrm{EP}_{4}$ and the 
mRNA for the CRH receptor $\mathrm{R} 1$ have been detected in nonpregnant human endometrium across the menstrual cycle (Di Blasio et al. 1997, Milne et al. 2001). The nature of RLX binding sites has long been an enigma. Only recently have two orphan receptors, LGR7 and LGR8, been shown to serve as RLX receptors (Hsu et al. 2002, Sudo et al. 2002). LGR7 and LGR8 belong to the subgroup of leucine-rich repeat-containing G-proteincoupled receptors (as do the gonadotrophin and thyrotrophin receptors) characterized by a long extracellular domain. Although interaction of RLX with these receptors clearly results in accumulation of cAMP, the signalling pathway does not appear solely to involve activation of adenylyl cyclase by the Gs $\alpha$ subunit. Intriguingly, RLXinduced cAMP production can be blocked by tyrosine kinase inhibitors (Bartsch et al. 2001). Incubation of ESC with RLX leads to rapid phosphorylation of the mitogen activated protein kinase (MAPK) kinase, MEK, followed by phosphorylation of MAPK. Subsequently, CREB is phosphorylated on Ser-133, the same site that is the target of phosphorylation by PKA (Zhang et al. 2002). In this context, it should be noted that in recent years new paradigms have emerged which go beyond the classical view of GPCR signalling being solely effected by G-proteins. Ligand-activated GPCR can associate with a variety of intracellular proteins including arrestins, G-protein-coupled receptor kinases (GRK), or proteins containing SH3 domains. These interactions couple the receptors to diverse intracellular signalling pathways (Hall et al. 1999, Marinissen \& Gutkind 2001).

Phosphodiesterases It is not only the rate of synthesis that determines the intracellular level of cAMP, but also its degradation. Members of the large family of phosphodiesterases convert cAMP to AMP which no longer stimulates PKA activity (Mehats et al. 2002). It is tempting to speculate that the sustained increase in cellular cAMP observed in decidualizing ESC is, at least in part, due to inhibition of phosphodiesterase activity. This may be brought about by the proposed coupling of RLX receptor signalling to the tyrosine kinase pathway and inhibition of phosphodiesterase activity by tyrosine phosphorylation (Bartsch et al. 2001, Ivell 2002).

PKA composition An important determinant of PKA activity and subcellular localization is the composition of the holoenzmye (Skålhegg \& Taskén 2000). Four isoforms of the regulatory subunit (RI $\alpha, \mathrm{RI} \beta, \mathrm{RII} \alpha, \mathrm{RII} \beta)$ and of the catalytic subunit $(\mathrm{C} \alpha, \mathrm{C} \beta, \mathrm{C} \gamma, \operatorname{PrKX})$ have been described (Taskén et al. 1997). Decidualizing treatment of ESC with RLX leads to a marked and specific downregulation of RI $\alpha$ protein, whereas the levels of RI $\beta$, RII $\alpha$, RII $\beta$ and of the C-subunits remain unchanged (Telgmann et al. 1997). As a consequence of reduced total $\mathrm{R}$-subunit levels, the $\mathrm{R}: \mathrm{C}$ ratio is shifted towards the $\mathrm{C}$-subunits, presumably resulting in a net increase in free, activated $\mathrm{C}$ protein and an increase in target protein phosphorylation.

CREM isoform expression Among the nuclear targets of PKA C-subunit are CREB and CREM. Their core region is a bipartite transactivation domain, consisting of one or two glutamine-rich regions $(\mathrm{Q} 1$ and $\mathrm{Q} 2)$, and the central kinase-inducible domain (KID) harbouring the phosphorylation sites (Mayr \& Montminy 2001). Due to alternative splicing, alternative translation initiaton events, or alternative promoter usage, these transcription factors can be expressed in a multitude of isoforms (Walker \& Habener 1996, Gellersen et al. 1997, 2002). Depending on the presence or absence of constituents of the transactivation domain, these isoforms are transcriptional activators or repressors (Mayr \& Montminy 2001). While the expression of CREB is largely constitutive in many systems, its action being tightly regulated by phosphorylation and de-phosphorylation events, the CREM gene carries an internal, highly cAMP-inducible promoter P2 (Molina et al. 1993). Transcripts generated from $\mathrm{P} 2$ encode the C-terminal bZIP region but are devoid of the $\mathrm{N}$ terminal transactivation functions. The translation product is known as ICER (inducible cAMP early repressor); through homodimerization or heterodimerization with other CREM/CREB isoforms it functions as a potent repressor and establishes a negative feedback loop to downregulate transcription of cAMP-induced promoters including its own. By this mechanism a cAMP-mediated signal is terminated (Foulkes et al. 1996). However, ESC again represent an exception to this concept. When exposed to long-term treatment with RLX or cAMP analogue, they do not show the expected transient increase in ICER expression but a persistent upregulation of ICER, indicating a permissiveness of the cells to the ongoing stimulation of cAMP signalling (Gellersen et al. 1997).

Coactivators The transcriptional coactivator CBP (or its paralogue p300) had originally been identified based on its ability to bind to CREB (Chrivia et al. 1993). It is now recognized as an integrator for a large number of transcriptional signals, owing to its interaction with transcription factors of surprisingly diverse nature on the one hand and RNA polymerase II complexes on the other hand, thus establishing contact between specific inputs and the basal transcription machinery (Janknecht \& Hunter 1996, Kamei et al. 1996). It is known to interact with, and enhance the activity of, CCAAT/enhancer-binding protein $\beta(\mathrm{C} / \mathrm{EBP} \beta)$ (Mink et al. 1997) which is an important mediator of cAMP signalling in ESC, as will be outlined below (Pohnke et al. 1999). Furthermore, CBP is recruited to preinitiation complexes containing steroid hormone receptors through the $160 \mathrm{kDa}$ steroid receptor coactivator proteins including SRC-1 (Smith et al. 1996). To date, our knowledge of the expression profiles of coactivators and corepressors, and of their potential 
hormone-dependency, in human endometrium is very limited. At least the presence of SRC-1 has been demonstrated in endometrial stromal cells throughout the menstrual cycle, and in cultured ESC (Brosens et al. 1999, Gregory et al. 2002, Wieser et al. 2002).

Novel cAMP-binding proteins Recently, novel cAMP-binding proteins have been identified, the cAMPguanine nucleotide exchange factors or EPACs (exchange protein activated by cAMP). These mediate PKAindependent signal transduction and couple the cAMP pathway to the p38 MAPK and phosphatidylinositol 3-kinase (PI3K) signalling cascades (Richards 2001). Notably, EPAC and PKA can mediate opposing effects of cAMP on downstream targets (Mei et al. 2002). The role of EPACs in mediating the cAMP responses in human endometrium remains to be determined. However, treatment of undifferentiated primary ESC with 8-p CPT-2'O-methyl-cAMP, a novel EPAC-specific cAMP analoque (Enserink et al. 2002), fails to elicit a decidual phenotype, suggesting that cAMP-dependent differentiation is predominantly or exclusively mediated through activation of PKA (authors' unpublished observations).

\section{Downstream events of $c A M P$ signalling in ESC: analysis of} the decidual PRL promoter

The onset of PRL production in vivo in endometrial stromal cells of the late secretory phase is recapitulated in cultured ESC when they are exposed to the appropriate decidualizing stimuli (Daly et al. 1983, Irwin et al. 1989, Tabanelli et al. 1992, Lane et al. 1994). Activation of the hitherto silent PRL gene in decidualizing cells serves as an exquisite marker of differentiation (Christian et al. 2001a). It has to be noted that the PRL gene in the decidua is transcribed from an alternative promoter located $6 \mathrm{~kb}$ upstream of the pituitary PRL promoter and therefore underlies completely different regulatory mechanisms (Berwaer et al. 1994, Gellersen et al. 1994). Transcription from the decidual PRL (dPRL) promoter adds a noncoding exon (exon 1a) to the PRL mRNA, the resulting protein, however, is identical to that produced in the pituitary (DiMattia et al. 1990). Utilization of an alternative decidua-specific PRL promoter has so far only been demonstrated in humans and primates, which excludes in vivo and in vitro experimentation in rodent models for understanding this aspect of decidualization (Brown \& Bethea 1994, Frasor et al. 1999).

CCAAT/enhancer-binding protein $\boldsymbol{\beta}$ (C/EBP $\beta)$ We have exploited the dPRL promoter as a tool to identify transcription factors relevant to decidualization. Just as morphological decidualization of cultured ESC is achieved within 2-4 days of treatment with a cAMP analogue, dPRL mRNA expression and PRL secretion become detectable within this time frame (Fig. 2) (Telgmann et al. 1997, Telgmann \& Gellersen 1998). In order to investigate whether this induction is due to transcriptional activation, we performed transient transfection experiments in primary ESC and observed a biphasic pattern of cAMP-mediated induction of the dPRL promoter. Whereas a CRE-like sequence in close proximity to the transcriptional start site conferred a rapid but weak and transient induction on the promoter, a delayed but strong and persistent stimulation of promoter activity was mediated by the region $-332 /-270$ relative to the start site (Telgmann et al. 1997). The time course of induction, and the lack of CRE-like sequences within this region suggested an indirect mode of activation. The element - 332/ -270 contains two binding sites for C/EBPs which constitute another subgroup of bZIP transcription factors (Ramji \& Foka 2002). Among the various members of this group, $\mathrm{C} / \mathrm{EBP} \beta$ is the predominant form in decidualized stromal cells (Pohnke et al. 1999). Of note, C/EBP $\beta$ has been recognized as essential for female reproduction; its absence obliterates ovulation, breast development and function (Sterneck et al. 1997, Robinson et al. 1998, Seagroves et al. 1998). The C/EBP binding sites in the dPRL promoter were shown to be crucial for cAMPinduced activation, revealing $\mathrm{C} / \mathrm{EBP} \beta$ as a central mediator of the cAMP signal towards decidualization (Pohnke et al. 1999). Not only is C/EBP $\beta$ induced by cAMP in cultured ESC, it also shows a striking increase in expression in vivo in stromal cell nuclei of the late secretory phase (Christian et al. 2002b). There are two isoforms of $\mathrm{C} / \mathrm{EBP} \beta$, the full-length liver-enriched activating protein (LAP) and the truncated liver-enriched inhibitory protein (LIP). The latter lacks the $\mathrm{N}$-terminal transactivation domains of LAP and acts as a potent repressor of C/EBPdependent transcription (Descombes \& Schibler 1991). Western blot analysis studies showed that only LAP is present in normal non-pregnant human endometrium (Christian et al. 2002b).

Forkhead proteins In addition to binding to their cognate DNA sequences as homo- or heterodimers, $\mathrm{C} / \mathrm{EBPs}$ have been shown to engage in protein-protein interactions with a wide variety of nuclear proteins. Investigating $\mathrm{C} / \mathrm{EBP} \beta$-mediated activation of the $\mathrm{dPRL}$ promoter further, we identified a member of the family of forkhead/winged helix proteins (Burgering \& Kops 2002), FoxO1a (FKHR), as a novel interacting partner (Christian et al. 2002b). FoxO1a and the other members of the FoxO subclass of forkhead transcription factors FoxO4 (AFX) and FoxO3a (FKHRL1) (Kaestner et al. 2000) have been shown to control the expression of genes essential for metabolic responses, cell cycle regulation and apoptosis, and confer resistance to oxidative stress (Brunet et al. 1999, Guo et al. 1999, Dijkers et al. 2000, Medema et al. 2000, Furukawa-Hibi et al. 2002, Kops et al. 2002a,b, Scott et al. 2002). FoxO1a expression is induced by cAMP in 


\section{Undifferentiated ESC}
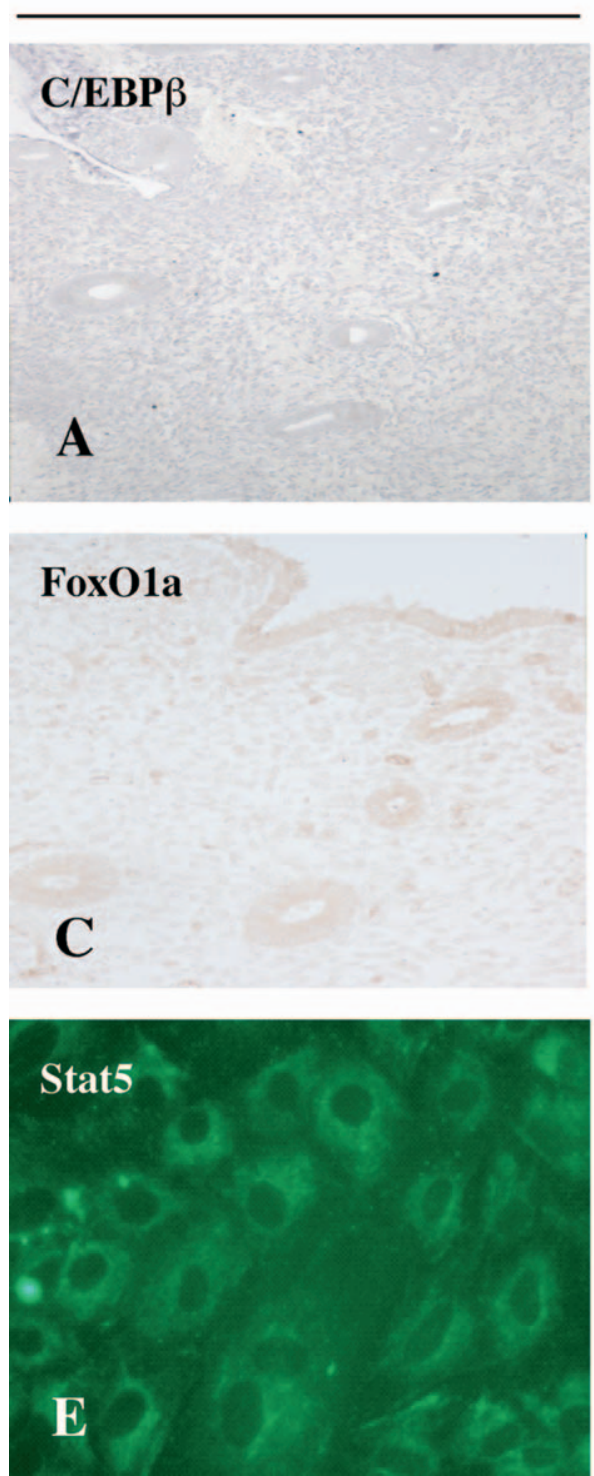

\section{Differentiating ESC}
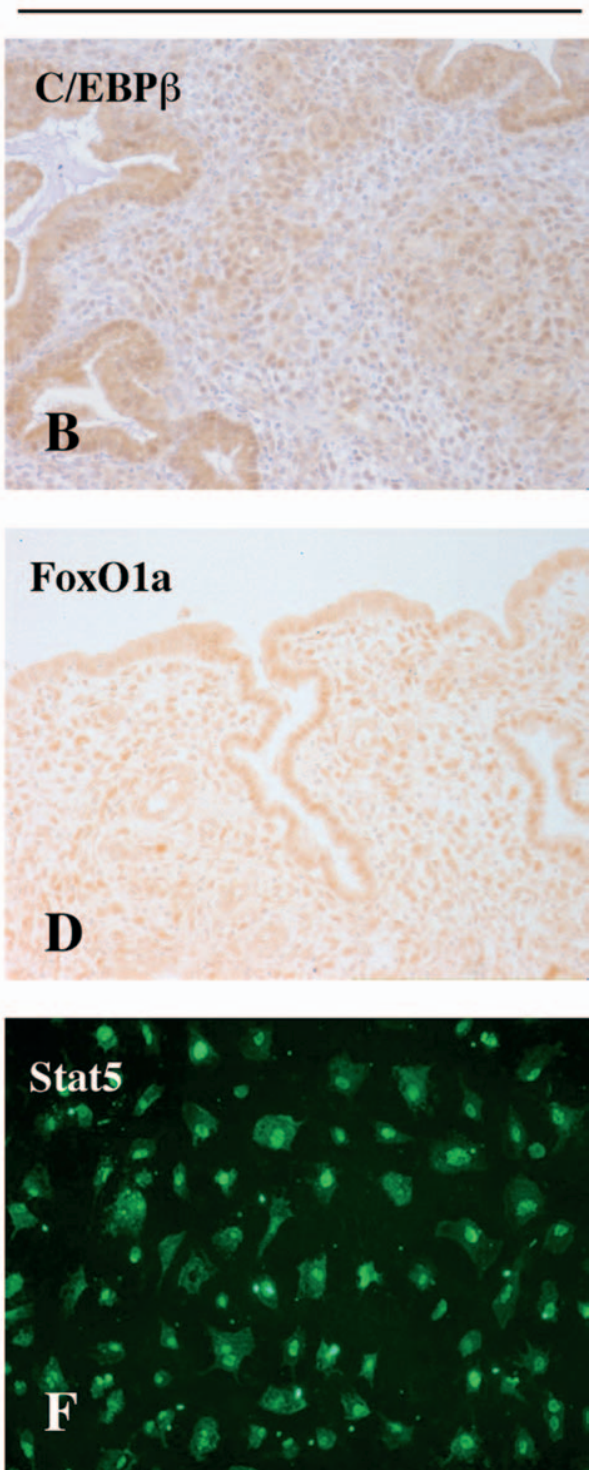

Figure 3 Expression of C/EBP $\beta$, FoxO1a, and Stat5 in differentiating ESC. (A, C) Proliferative phase endometrium shows very weak FoxO1a immunostaining confined to glandular and surface epithelial cells. In contrast, there is no discernible C/EBP $\beta$ expression in either glandular or stromal compartments. $(B, D)$ Late secretory phase endometrium showing strong $C / E B P \beta$ and FoxO1a expression in stroma and glands. (E) Stat5 expression in undifferentiated ESC in culture is confined to the cytoplasm. (F) Upon treatment with 8-bromo-cAMP and a progestin, Stat5 accumulates in the cell nuclei.

cultured ESC, and, in striking parallelism to C/EBP $\beta$, FoxO1a protein accumulates in the nuclei of decidualized stromal cells in vivo (Fig. 3). FoxO1a and C/EBP $\beta$ physically interact and cooperatively activate the dPRL promoter (Christian et al. 2002b). FoxO are targets of protein kinase $\mathrm{B}(\mathrm{PKB} / \mathrm{Akt})$, a serine/threonine kinase located downstream of PI3K. FoxO1a has three putative
PKB/Akt phosphorylation sites (Thr-24, Ser-256, Ser319) which are also conserved in DAF16, the nematode Caenorhabditis elegans homologue. Upon PKB/Akt phosphorylation, DAF16 and its human counterparts are retained in the cytoplasm, and their exlusion from the nucleus is associated with reduced transcriptional activity (Biggs et al. 1999, Brunet et al. 1999, Rena et al. 1999). 
The observation that FoxO1a accumulates in the nuclei of cAMP-treated ESC suggests that the PI3K/PKB signalling pathway is suppressed upon decidualization. This is in agreement with in vivo studies demonstrating that PTEN, a tumour suppressor gene and potent inhibitor of the $\mathrm{PI} 3 \mathrm{~K} / \mathrm{PKB}$ signalling pathway, is highly expressed in the cytoplasm of stromal cells undergoing decidual transformation during the late secretory phase of the menstrual cycle (Mutter et al. 2000).

\section{Signal transducer and activator of transcription 5} (Stat5) A recent study demonstrated that Stat5 also enhances the activity of the $-332 /-270 \mathrm{dPRL}$ promoter region in human ESC (Mak et al. 2002). Stat5 belongs to the STAT family of latent transcription factors which have been implicated in growth and differentiation of many tissues including adipocytes, hepatocytes, and mammary epithelial cells (Darnell 1997). Treatment of primary ESC cultures with cAMP with or without progestin for two or more days results in induction, phosphorylation, dimerization, and nuclear translocation of Stat5 (Fig. 3) (Mak et al. 2002). Stats are activated by numerous cytokines and peptide growth factors. They lack intrinsic kinase activity and, in most cell systems, require targeted phosphorylation by receptor-associated Janus kinases (Jaks) for signal transduction (Schindler \& Darnell 1995, Darnell 1997). However, Mak and co-workers demonstrated that nuclear accumulation of phospho-Stat5 in ESC is independent of Jak activity, indicating a role for other activating kinases (Mak et al. 2002). One such factor capable of activating Stat5 in a Jak-independent manner is c-Src kinase (Olayioye et al. 1999), which is highly expressed in differentiating ESC (Maruyama et al. 1999, Yamamoto et al. 2002).

\section{Biochemical mechanism of decidualization: role of PR}

\section{Progesterone signal transduction: role of nuclear PR}

Ovarian progesterone is required for all aspects of female reproductive function including sexual behaviour, mammary gland development, ovulation, implantation, and maintenance of pregnancy (Conneely \& Lydon 2000, Mulac-Jericevic et al. 2000, Rider 2002). Genomic actions of progesterone in target cells are mediated through activation of its nuclear receptor. The progesterone receptor $(\mathrm{PR})$ is a member of the superfamily of ligand-activated transcription factors that exhibit sequence-specific DNA binding to regulatory regions of their target genes. Two isoforms exist, $\mathrm{PR}-\mathrm{A}$ and $\mathrm{PR}-\mathrm{B}$, which arise from different promoter usage in a single gene. PR-B differs from PR-A in that it contains an additional 164 amino acids at the N-terminus (B-upstream sequence, BUS) (Kastner et al. 1990). Although the PR isoforms display indistin- guishable hormone- and DNA-binding affinities, several studies have shown that, depending on the cell- and promoter context, PR-A and PR-B have remarkably different transcriptional activities. In general, the PR-A isoform is transcriptionally much less active and functions as a dominant inhibitor of transcription by PR-B and various other steroid receptors (Tung et al. 1993, Vegeto et al. 1993, Sartorius et al. 1994a, Wen et al. 1994). Various models exist to explain the weak transactivation potential of PR-A compared with PR-B. PR-A shares with PR-B the activation functions AF-1 and AF-2 but lacks AF-3, which is situated in the BUS segment specific to PR-B (Sartorius et al. 1994b). AF-1 is a constitutive activation domain N-terminal to the DNA-binding domain (DBD) while the ligand-dependent activation function AF-2 is located in the ligand-binding domain (LBD) (Meyer et al. 1992). The N-terminal segment of PR-A harbours an inhibitory function, termed IF or ID, which represses AF-1 or AF-2, but not AF-3. Removal of IF/ID converts PR-A into a strong transcriptional activator. The BUS domain is thought to repress IF/ID, thereby rendering PR-B a much more potent activator of transcription than PR-A (Hovland et al. 1998). Recently a SUMO-1 (small ubiquitin-like modifier-1) binding motif has been identified within the IF domain of PR (Abdel-Hafiz et al. 2002). Sumoylation involves covalent binding of SUMO (SUMO-1, SUMO-2, or SUMO-3) to target proteins. Like ubiquitination, sumoylation uses a battery of activating (E1), conjugating (E2), and ligating (E3) enzymes. In contrast to ubiquitination, sumoylation does not lead to protein degradation. Instead, SUMO-1 modification of transcription factors has profound consequences on protein stability, subcellular localization, interactions with other nuclear proteins, and transcriptional activity (Melchior 2000, Hochstrasser 2001, Muller et al. 2001). Mutation of the N-terminal SUMO-1 binding motif markedly increases the transcriptional activity of PR-A and PR-B and abolishes the transrepression activity of PR-A (AbdelHafiz et al. 2002). It has also been reported that the lower transactivation potential of PR-A may be a result of its higher affinity for the corepressor SMRT (silencing mediator of retinoid and thyroid hormone receptor) and its less efficient recruitment of the coactivator SRC-1 (Giangrande et al. 2000).

Binding of ligand induces a conformational change in the receptor, resulting in phosphorylation, dissociation from heat shock proteins, dimerization, sumoylation of a subpopulation of the receptor, and binding and activation of specific response elements in the promoter region of target genes. The latter requires further interaction of the AF-2 region with SRCs resulting in recruitment of other SRC-associated histone acetyltransferases (CBP and pCAF) and the methyltransferase CARM1 (Chen et al. 1999, Wardell et al. 2002). Hormone binding is not an absolute requirement for the activation of steroid receptors. For instance, elevated intracellular cAMP levels and 
activation of the PKA pathway can induce ligandindependent activation of chicken PR (cPR), the androgen receptor (AR), and the oestrogen receptor (ER) in certain cell systems (Denner et al. 1990, Aronica \& Katzenellenbogen 1993, Nazareth \& Weigel 1996). To our knowledge, there is no convincing evidence that PKA, or any other signalling pathway, can activate unliganded PR in human reproductive tissues. However, cAMP analogues such as 8-bromo-cAMP enhance hormone-dependent transcriptional activity of PR and can convert some antiprogestins, such as RU486, into PR agonists. The mechanism by which cAMP potentiates PR activity is not entirely understood but is thought to involve disruption of the interaction between the receptor and the corepressors $\mathrm{NCoR}$ and SMRT and increased cooperation between coactivators such as SRC-1 and CBP (Wagner et al. 1998, Rowan et al. 2000a,b).

Finally, it should be noted that liganded PR can profoundly modulate gene expression through proteinprotein interaction with other transcription factors rather than through direct interaction with DNA. In fact, our current evidence indicates that this is the dominant mechanism of PR action in differentiating human ESC (see below).

\section{Progesterone signal transduction: role of membrane PR}

Progesterone, like other steroid hormones, can trigger rapid cytoplasmic events that are independent of its genomic actions (Boonyaratanakornkit et al. 2001, Cato et al. 2002). One of the best characterized biological examples is the resumption of meiosis in Xenopus oocytes arrested at the G2 to prophase border in response to progesterone (Maller 2001). It has been suggested that these rapid non-genomic effects of progesterone are mediated by binding of $\mathrm{PR}$ to the $\mathrm{SH} 3$ domain of $\mathrm{c}-\mathrm{Src}$, resulting in phosphorylation and activation of the $\mathrm{p} 42 / 44$ MAPK signal transduction pathway (Boonyaratanakornkit et al. 2001). However, very recently a family of membrane progestin receptors (mPR- $\alpha, \mathrm{mPR}-\beta, \mathrm{mPR}-\gamma)$ has been discovered. These novel membrane PRs are structurally distinct from their nuclear counterparts but related to GPCRs (Zhu et al. 2003a,b). The mPR- $\alpha$, first cloned from sea trout, is thought to be coupled to an inhibitory G protein. This mechanism of action of the mPR- $\alpha$ is consistent with the rapid inhibition of adenylyl cyclase activity observed in progestin-treated Xenopus oocytes. Moreover, injection of zebrafish oocytes with zebrafish mPR- $\alpha$ antisense blocked steroid-induced oocyte maturation (Zhu et al. 2003b).

The human mPR- $\alpha$ is predominantly expressed in reproductive tissues (Zhu et al. 2003a). No information is as yet available on its role in differentiating ESCs but the fact that $\mathrm{mPR}-\alpha$ is present in the uterus and placenta will undoubtedly trigger renewed interest in the impact of progesterone on cytoplasmic signalling events in female reproduction.

Progesterone signalling in ESC: analysis of the decidual PRL promoter

Several lines of evidence support the concept that interaction of nuclear PR with other transcription factors mediates the progesterone effects in differentiating endometrial stroma. First, decidualization, in vivo and in vitro, is associated with rapid down-regulation of PR-B rendering PR-A the dominant isoform (Wang et al. 1998, Brosens et al. 1999, Mote et al. 1999). The critical role of this receptor isoform in the stroma is further demonstrated by the lack of a decidual response in uteri of PR-A deficient mice (Mulac-Jericevic et al. 2000). As mentioned, binding of PR-A to its DNA response element generally elicits a very weak transcriptional response and it appears counterintuitive that this mechanism would suffice to induce the profound cellular reprogramming which has to be maintained throughout pregnancy. Secondly, progestin treatment of primary cultures does elicit modest expression of decidual markers, such as IGFBP-1 and PRL, but only after several days of stimulation by which time the intracellular cAMP levels are increasing (Brar et al. 1997). Many decidua-specific genes, including the decidual PRL gene, do not have palindromic progesterone response elements in their promoters. Furthermore, in transient transfection experiments, progestin treatment alone fails to activate the dPRL promoter in the presence or absence of overexpressed PR-A or PR-B (Gellersen et al. 1994, Brosens et al. 1999, Mak et al. 2002). However, progestins markedly enhance $\mathrm{dPRL}$ promoter activity, as well as PRL mRNA and protein expression in cells pretreated with cAMP for approximately two days (Brosens et al. 1999). These observations suggested that the PKA signalling pathway may sensitize ESC to progesterone through induction or modification of transcription factors or coactivators capable of modulating PR function. This does indeed appear to be the case.

PR and C/EBP $\boldsymbol{\beta}$ The presence of a PR binding half-site adjacent to the C/EBP binding sites in the APRL - 332/ -270 promoter element prompted us to investigate whether C/EBP $\beta$ might tether PR to the dPRL promoter. We demonstrated that PR can physically associate with the two C/EBP $\beta$ isoforms, LAP and LIP. This interaction is mediated by the DBD of the receptor and the bZIP domain of C/EBP $\beta$ (Christian et al. 2002a). The functional consequences of this interaction are dependent upon the relative ratios of $\mathrm{PR}$ and $\mathrm{C} / \mathrm{EBP} \beta$ isoforms in the cell. Transfection studies demonstrated that PR-A, but not PR-B, greatly enhances LAP-dependent activation of the $\mathrm{dPRL}-332 /-270$ promoter region as well as a reporter construct driven by a single $\mathrm{C} / \mathrm{EBP} \beta$ response element in 


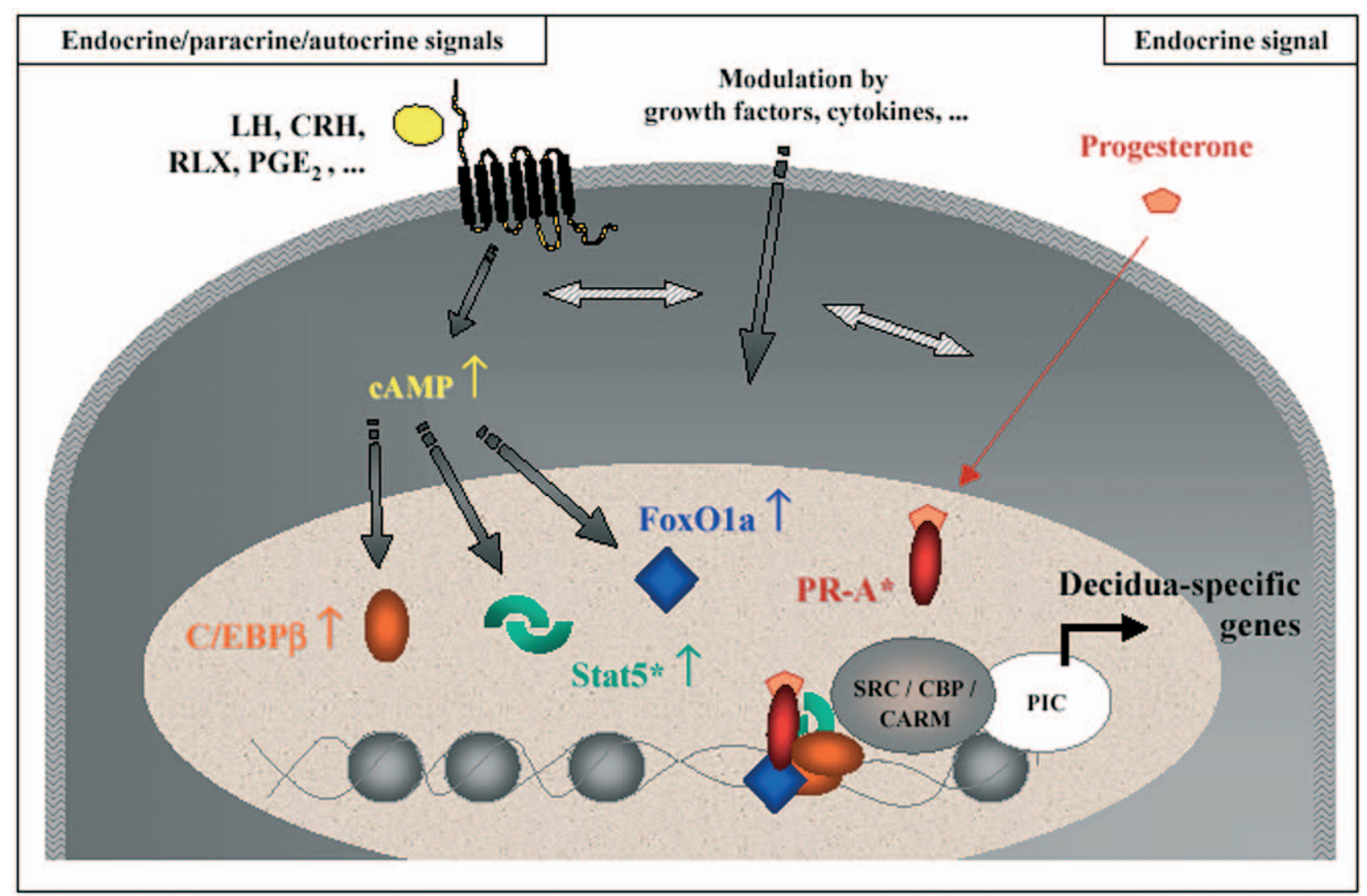

Figure 4 Model for cross-talk between PR-A and cAMP signalling in differentiating human ESC. Elevation of cAMP upon activation of GPCRs promotes expression and nuclear accumulation of C/EBP $\beta$, FoxO1a and activated Stat5 $(*)$. These factors can interact with ligand-activated PR-A $\left(^{*}\right)$ to initiate transcription of decidua-specific genes. For detailed explanation see text. PIC, preinitiation complex.

a ligand-dependent manner. Conversely, overexpression of LIP, but not LAP, enhances PR-B transactivation of single and complex progesterone response elementdependent promoters (Christian et al. 2002a). Recently, another bZIP transcription factor, Jun dimerization protein 2 (JDP-2), was identified capable of interacting with the $\mathrm{DBD}$ of $\mathrm{PR}$, thereby stabilizing the interaction with general coactivators, and enhancing PR-B-dependent transcription (Wardell et al. 2002). JDP-2 belongs to the AP-1 family of transcription factors and, like LIP, lacks a transactivation domain and functions as a repressor of c-Jun transactivation of AP-1 response elements. In the context of decidualization, however, PR-A and LAP are the predominant isoforms and, hence, progesterone may be essential for maintaining and enhancing the expression of $\mathrm{C} / \mathrm{EBP} \beta$-dependent genes in the decidua. Further support for the important role of PR-A in decidualization stems from the finding that the expression of IGFBP-1, another major decidual product which is regulated by progesterone and cAMP signalling (Tseng et al. 1992, Frank et al. 1994, Kim et al. 1998), is more strongly induced by ligandactivated PR-A than PR-B (Gao et al. 2000).
PR, FoxO1a and Stat5 In addition to C/EBP $\beta$, FoxO1a and Stat5 are cAMP-induced transcription factors in decidualizing ESC and have also been shown to interact with PR (Richer et al. 1998, Schuur et al. 2001, Zhao et al. 2001, Christian et al. 2002b, Mak et al. 2002). Induction of the dPRL promoter by cAMP plus progestin is markedly enhanced by Stat 5 and abolished by coexpression of a dominant negative to Stat5 (Mak et al. 2002). FoxO1a enhances the activity of the dPRL promoter cooperatively with $\mathrm{C} / \mathrm{EBP} \beta$ through the discrete -332 / -270 region which also harbours the imperfect PR binding site (Christian et al. 2002b). Intriguingly, FoxO1a and $\mathrm{C} / \mathrm{EBP} \beta$, in addition to $\mathrm{PR}$, are also involved in transcriptional regulation of the IGFBP-1 promoter (Ghosh et al. 2001, Kim et al. 2003).

\section{Convergence of progesterone and $A M P$ signalling}

Taken together, these observations suggest a role for $\mathrm{PR}$ as a platform for the formation of a decidua-specific transcriptional complex involving such diverse transcription factors as FoxO, C/EBP and Stat5 (Fig. 4). This model is in 
Table 2 Mutual enhancement of decidualization by progesterone and cAMP-mediated stimulation in vitro

\section{Enhancement of}

$\begin{array}{ll}\begin{array}{ll}\text { Effector 1 } \\ \text { CAMP }\end{array} & \begin{array}{l}\text { Effector 2 } \\ \text { Progesterone }\end{array} \\ \text { CRH } & \begin{array}{l}\text { Progesterone } \\ \text { hCG }\end{array} \\ \text { PGE }_{2} & \text { Progesterone } \\ \text { Progesterone } & \begin{array}{l}\text { Progesterone } \\ \text { RLX }\end{array} \\ \text { Progesterone } & \mathrm{PGE}_{2}\end{array}$

\author{
PRL production \\ dPRL promoter activity \\ PRL production \\ PRL production \\ CAMP production \\ PRL mRNA expression \\ IGFBP-1 mRNA expression \\ PRL production \\ IGFBP-1 production
}

Reference

Brosens et al. (1999)

Ferrari et al. (1995)

Nemansky et al. (1998)

Houserman et al. (1989)

Tseng et al. (1992)

Frank et al. (1994) keeping with a number of additional observations. First, treatment of ESC with antiprogestins inhibits cAMPinduced $\mathrm{dPRL}$ expression which suggests that even the unliganded PR may be recruited in a ternary, albeit less functional, complex. Furthermore, in the absence of progesterone this transcriptosome is likely to be unstable as demonstrated by the inability of cAMP to maintain the expression of decidua-specific genes in long-term cultures (Fig. 2). Finally, transient and stable overexpression of either PR isoforms inhibit cAMP-induced dPRL promoter activity and protein expression respectively (Brosens et al. 1999). This could be explained by the ability of suprastochiometric PR levels to interfere with the assembly of a functional complex through squelching and sequestering of essential transcriptional partners and coactivators.

Intriguingly, microarray studies in the breast cancer cell line T47D identified STAT5, C/EBP $\beta$, and FoxO1a as genes under direct transcriptional control of PR (Richer et al. 2002). Although the mechanism underlying these paradoxical cell-specific responses is not known, it may suggest that in the human endometrium PR only acquires full transcriptional activity in the presence of elevated cAMP levels. Steroid hormone receptors and their SRC complexes have been identified as down-stream targets of a variety of different signalling pathways, including PKA, PI3K/PKB, and MAPK (Lange et al. 1998, 2000, Rowan et al. 2000a,b, Campbell et al. 2001, Shen et al. 2001). Furthermore, the abundance and activity of many transcription factors, including PR, are regulated by diverse posttranslational modifications, including acetylation, ubiquitination, and sumoylation. It therefore appears possible that targeted covalent modification of $\mathrm{PR}$ and/or its coactivators, in response to cAMP-dependent activation of discrete or diverse signal transduction pathways, is necessary for full transcriptional competence.

\section{Hormonal control of decidualization - from cultured ESC to the intact uterus}

Numerous examples illustrate the mutual potentiation of cAMP- and progestin-stimulated effects on cultured ESC
(Table 2). With the accumulated evidence for a convergence of CAMP- and PR-signalling pathways derived from in vitro models - what are the correlates in vivo? The key role of progesterone in orchestrating remodelling of the postovulatory endometrium is unquestioned. However, the input of GPCR-mediated signals in vivo, beyond the indirect influence of LH and follicle-stimulating hormone (FSH) acting on the ovary, may not have been fully acknowledged. The preovulatory LH surge, followed by the FSH peak, may provide an initiating signal by directly acting on endometrial gonadotrophin receptors. LH/hCG receptors, along with various $\mathrm{G}$-protein subunits including $\mathrm{Gs} \alpha$, are present in membrane preparations from endometrial biopsies. In artificial cycles under hormone replacement therapy, Gs $\alpha$ was found to increase with the administration of progesterone for 3-9 days (Bernardini et al. 1995). Stimulatable adenylate cyclase activity in the human endometrium increases during the menstrual cycle, and the cAMP content in biopsies obtained from patients during the secretory phase is higher than that in the proliferative phase (Bergamini et al. 1985, Tanaka et al. 1993). As the secretory phase progresses, circulating LH and FSH levels fall, but paracrine/autocrine mechanisms such as the local production of RLX, CRH and hCG $\beta$-subunit may serve to sustain cAMP signalling (Wolkersdörfer et al. 1998, Gravanis et al. 1999, Palejawa et al. 2002). Furthermore, PGE synthase and its product, $\mathrm{PGE}_{2}$, are found in the endometrium throughout the cycle (Milne et al. 2001). In case of successful implantation, the trophoblast-derived hCG may take over the gonadotrophic stimulation of the decidua. The notion that progesterone-dependent differentiation of the endometrium requires elevated intracellular cAMP levels is being exploited in clinical practice. For instance human menopausal gonadotrophins (hMG) and hCG have been used to treat women with unexplained recurrent miscarriages, although larger controlled trials are required to confirm the efficacy of this approach (Scott \& Pattison 2000, Li et al. 2002).

The highly defined spatial and temporal pattern of differentiation of the human endometrium is likely to be controlled by a balance of inhibitory and stimulatory 
signals. The endometrium is known to express several factors capable of inhibiting decidual PRL expression in vitro, including annexin-1, retinoic acid, transforming growth factor (TGF) $\beta$, endothelins, and proinflammatory cytokines such as interleukin (IL)-1, tumour necrosis factor (TNF)- $\alpha$, and interferon (IFN) $-\gamma$ (Kariya et al. 1991, Pihoker et al. 1991, Chao et al. 1993, Jikihara \& Handwerger 1994, Brar et al. 1996, Kubota et al. 1997, Christian et al. 2001b). Recently, we demonstrated that treatment with IFN- $\gamma$, resulting in activation of the Stat1 signalling pathway, potently represses $\mathrm{dPRL}$ promoter activity in differentiating ESC (Christian et al. 2001b). IFN- $\gamma$, or type II interferon, is an immunomodulatory $\mathrm{T}$ helper 1-type cytokine secreted predominantly by activated $\mathrm{T}$ lymphocytes and natural killer cells. In the endometrium, IFN- $\gamma$ expression is markedly, albeit transiently, increased in the early secretory phase of the cycle. This peak of IFN- $\gamma$ expression coincides with the influx of uterine NK cells but precedes differentiation of perivascular endometrial stromal cells (Kumar et al. 2001). An altered profile of uterine NK cells and persistently elevated endometrial IFN- $\gamma$ expression in the secretory phase of the cycle has been documented in women with a history of recurrent miscarriages (Lachapelle et al. 1996, Lim et al. 2000). These observations underscore the notion that events in the conception cycle have a profound impact on subsequent pregnancy outcome.

\section{Conclusion}

The physiological importance of the decidual reaction in ensuring appropriate placenta formation and function is beyond doubt. Furthermore, from a clinical viewpoint, a spectrum of pregnancy disorders, including recurrent miscarriages, fetal growth restriction, placental abruption, and preeclampsia, are caused by uteroplacental dysfunction characterized by impaired decidual response, aberrant immune reaction, and spiral artery vasculopathy (Brosens et al. 2002). From a biochemical perspective, decidualization appears at first a simple affair, requiring only elevation of the intracellular cAMP levels to sensitize the cells to the actions of progesterone. However, scratch beyond the surface and a myriad of signalling pathways, transcription factors and cross-talks are required to coordinate this temporary reprogramming of the endometrial stroma. Our understanding of the molecular mechanisms of ESC differentiation is far from complete and there is a long way still to go before we can translate this knowledge into effective new treatments for common reproductive disorders.

\section{Acknowledgements}

We would like to thank Dr Robert Pijnenborg for his inspirational comments and Drs John White and Ian Mak for the immunofluorescence images. This work was supported by a Wellcome Trust Clinician Scientist Fellowship 54043 (to J J B), a Deutsche Forschungsgemeinschaft Grant GE 748/7-1 (to B G), and a Royal Society Joint Project Grant.

\section{References}

Abdel-Hafiz H, Takimoto GS, Tung L \& Horwitz KB 2002 The inhibitory function in human progesterone receptor $\mathrm{N}$ termini binds SUMO-1 protein to regulate autoinhibition and transrepression. Journal of Biological Chemistry 277 33950-33956.

Aronica SM \& Katzenellenbogen BS 1993 Stimulation of estrogen receptor-mediated transcription and alteration in the phosphorylation state of the rat uterine estrogen receptor by estrogen, cyclic adenosine monophosphate, and insulin-like growth factor-I. Molecular Endocrinology 7 743-752.

Ashkar AA, Di Santo JP \& Croy BA 2000 Interferon $\gamma$ contributes to initiation of uterine vascular modification, decidual integrity, and uterine natural killer cell maturation during normal murine pregnancy. Journal of Experimental Medicine 192 259-270.

Bartsch O, Bartlick B \& Ivell R 2001 Relaxin signalling links tyrosine phosphorylation to phosphodiesterase and adenylyl cyclase activity. Molecular Human Reproduction 7 799-809.

Bergamini CM, Pansini F, Bettocchi Jr S, Segala V, Dallocchio F, Bagni B \& Mollica G 1985 Hormonal sensitivity of adenylate cyclase from human endometrium: modulation by estradiol. Journal of Steroid Biochemistry 22 299-303.

Bernardini L, Moretti-Rojas I, Brush M, Rojas FJ \& Balmaceda JP 1995 Status of hCG/LH receptor and G proteins in human endometrium during artificial cycles of hormone replacement therapy. Journal of the Society for Gynecological Investigation 2 630-635.

Berwaer M, Martial JA \& Davis JRE 1994 Characterization of an up-stream promoter directing extrapituitary expression of the human prolactin gene. Molecular Endocrinology 8 635-642.

Biggs WH 3rd, Meisenhelder J, Hunter T, Cavenee WK \& Arden KC 1999 Protein kinase B/Akt-mediated phosphorylation promotes nuclear exclusion of the winged helix transcription factor FKHR1. PNAS 96 7421-7426.

Bilinski P, Roopenian D \& Gossler A 1998 Maternal IL-11R $\alpha$ function is required for normal decidua and fetoplacental development in mice. Genes and Development 12 2234-2243.

Boonyaratanakornkit V, Scott MP, Ribon V, Sherman L, Anderson SM, Maller JL, Miller WT \& Edwards DP 2001 Progesterone receptor contains a proline-rich motif that directly interacts with $\mathrm{SH} 3$ domains and activates c-Src family tyrosine kinases. Molecular Cell 8 269-280.

Brar AK, Kessler CA, Meyer AJ, Cedars MI \& Jikihara H 1996 Retinoic acid suppresses in-vitro decidualization of human endometrial stromal cells. Molecular Human Reproduction 2 185-193.

Brar AK, Frank GR, Kessler CA, Cedars MI \& Handwerger S 1997 Progesterone-dependent decidualization of the human endometrium is mediated by cAMP. Endocrine 6 301-307.

Brar AK, Handwerger S, Kessler CA \& Aronow BJ 2001 Gene induction and categorical reprogramming during in vitro human endometrial fibroblast decidualization. Physiological Genomics 7 135-148.

Breyer RM, Bagdassarian CK, Myers SA \& Breyer MD 2001 Prostanoid receptors: subtypes and signaling. Annual Reviews of Pharmacology and Toxicology 41 661-690.

Brosens JJ, Hayashi N \& White JO 1999 Progesterone receptor regulates decidual prolactin expression in differentiating human endometrial stromal cells. Endocrinology 140 4809-4820.

Brosens JJ, Pijnenborg R \& Brosens IA 2002 The myometrial junctional zone spiral arteries in normal and abnormal pregnancies: 
a review of the literature. American Journal of Obstetrics and Gynecology 187 1416-1423.

Brown NA \& Bethea CL 1994 Cloning of decidual prolactin from rhesus macaque. Biology of Reproduction 50 543-552.

Brunet A, Bonni A, Zigmond MJ, Lin MZ, Juo P, Hu LS, Anderson MJ, Arden KC, Blenis J \& Greenberg ME 1999 Akt promotes cell survival by phosphorylating and inhibiting a Forkhead transcription factor. Cell 96 857-868.

Burgering BM \& Kops GJ 2002 Cell cycle and death control: long live Forkheads. Trends in Biochemical Sciences 27 352-360.

Campbell RA, Bhat-Nakshatri P, Patel NM, Constantinidou D, Ali S \& Nakshatri H 2001 Phosphatidylinositol 3-kinase/AKT-mediated activation of estrogen receptor $\alpha$ : a new model for anti-estrogen resistance. Journal of Biological Chemistry 276 9817-9824.

Cato AC, Nestl A \& Mink S 2002 Rapid actions of steroid receptors in cellular signaling pathways. Science's STKE 138 RE9.

Chao HS, Myers SE \& Handwerger S 1993 Endothelin inhibits basal and stimulated release of prolactin by human decidual cells. Endocrinology 133 505-510.

Chen D, Ma H, Hong H, Koh SS, Huang SM, Schurter BT, Aswad DW \& Stallcup MR 1999 Regulation of transcription by a protein methyltransferase. Science 284 2174-2177.

Christian M, Mak I, White JO \& Brosens JJ 2001a Mechanisms of decidualization. Reproductive BioMedicine Online 4 24-30.

Christian M, Marangos P, Mak I, McVey J, Barker F, White J \& Brosens JJ $2001 b$ Interferon $\gamma$ modulates prolactin and tissue factor expression in differentiating human endometrial stromal cells. Endocrinology 142 3142-3151.

Christian M, Pohnke Y, Kempf R, Gellersen B \& Brosens JJ 2002a Functional association of $\mathrm{PR}$ and CCAAT/enhancer-binding protein $\beta$ isoforms: promoter-dependent cooperation between PR-B and liver-enriched inhibitory protein, or liver-enriched activatory protein and PR-A in human endometrial stromal cells. Molecular Endocrinology 16 141-154.

Christian M, Zhang X, Schneider-Merck T, Unterman TG, Gellersen B, White JO \& Brosens JJ $2002 b$ Cyclic AMP-induced forkhead transcription factor, FKHR, cooperates with CCAAT/enhancerbinding protein $\beta$ in differentiating human endometrial stromal cells. Journal of Biological Chemistry 277 20825-20832.

Chrivia JC, Kwok RPS, Lamb N, Hagiwara M, Montminy MR \& Goodman RH 1993 Phosphorylated CREB binds specifically to the nuclear protein CBP. Nature 365 855-859.

Conneely OM \& Lydon JP 2000 Progesterone receptors in reproduction: functional impact of the $\mathrm{A}$ and $\mathrm{B}$ isoforms. Steroids $\mathbf{6 5}$ $571-577$

Daly DC, Maslar IA \& Riddick DH 1983 Prolactin production during in vitro decidualization of proliferative endometrium. American Journal of Obstetrics and Gynecology 145 672-678.

Darnell JE Jr 1997 STATs and gene regulation. Science 277 1630-1635.

Denner LA, Weigel NL, Maxwell BL, Schrader WT \& O'Malley BW 1990 Regulation of progesterone receptor-mediated transcription by phosphorylation. Science 250 1740-1743.

Descombes P \& Schibler U 1991 A liver-enriched transcriptional activator protein, LAP, and a transcriptional inhibitory protein, LIP, are translated from the same mRNA. Cell 67 569-579.

Dessauer CW, Posner BA \& Gilman AG 1996 Visualizing signal transduction: receptors, G-proteins, and adenylate cyclase. Clinical Science 91 527-537.

Di Blasio AM, Giraldi FP, Viganò P, Petraglia F, Vignali M \& Cavagnini F 1997 Expression of corticotropin-releasing hormone and its R1 receptor in human endometrial stromal cells. Journal of Clinical Endocrinology and Metabolism 82 1594-1597.

Dijkers PF, Medema RH, Pals C, Banerji L, Thomas NS, Lam EW, Burgering BM, Raaijmakers JA, Lammers JW, Koenderman L \& Coffer PJ 2000 Forkhead transcription factor FKHR-L1 modulates cytokine-dependent transcriptional regulation of p27 KIP1. Molecular and Cellular Biology 20 9138-9148.
DiMattia GE, Gellersen B, Duckworth ML \& Friesen HG 1990 Human prolactin gene expression. The use of an alternative noncoding exon in decidua and the IM-9-P3 lymphoblast cell line. Journal of Biological Chemistry 265 16412-16421.

Enserink JM, Christensen AE, de Rooij J, van Triest M, Schwede F, Genieser HG, Doskeland SO, Blank JL \& Bos JL 2002 A novel Epac-specific cAMP analogue demonstrates independent regulation of Rap1 and ERK. Nature Cell Biology 4 901-906.

Ferrari A, Petraglia F \& Gurpide E 1995 Corticotropin releasing factor decidualizes human endometrial stromal cells in vitro. Interaction with progestin. Journal of Steroid Biochemistry and Molecular Biology $\mathbf{5 4}$ 251-255.

Foulkes NS, Borjigin J, Snyder SH \& Sassone-Corsi P 1996 Transcriptional control of circadian hormone synthesis via the CREM feedback loop. PNAS 93 14140-14145.

Frank GR, Brar AK, Cedars MI \& Handwerger S 1994 Prostaglandin $\mathrm{E}_{2}$ enhances human endometrial stromal cell differentiation. Endocrinology 134 258-263.

Frasor J, Gaspar CA, Donnelly KM, Gibori G \& Fazleabas AT 1999 Expression of prolactin and its receptor in the baboon uterus during the menstrual cycle and pregnancy. Journal of Clinical Endocrinology and Metabolism 84 3344-3350.

Furukawa-Hibi Y, Yoshida-Araki K, Ohta T, Ikeda K \& Motoyama N 2002 FOXO forkhead transcription factors induce G2-M checkpoint in response to oxidative stress. Journal of Biological Chemistry 277 26729-26732.

Gao J, Mazella J, Tang M \& Tseng L 2000 Ligand-activated progesterone receptor isoform $\mathrm{hPR}-\mathrm{A}$ is a stronger transactivator than hPR-B for the expression of IGFBP-1 (insulin-like growth factor binding protein-1) in human endometrial stromal cells. Molecular Endocrinology 14 1954-1961.

Gellersen B, Kempf R, Telgmann R \& DiMattia GE 1994 Nonpituitary human prolactin gene transcription is independent of Pit-1 and differentially controlled in lymphocytes and in endometrial stroma. Molecular Endocrinology 8 356-373.

Gellersen B, Kempf R \& Telgmann R 1997 Human endometrial stromal cells express novel isoforms of the transcriptional modulator CREM and up-regulate ICER in the course of decidualization. Molecular Endocrinology 11 97-113.

Gellersen B, Kempf R, Sandhowe R, Weinbauer GF \& Behr R 2002 Novel leader exons of the cyclic adenosine $3^{\prime}, 5^{\prime}$-monophosphate response element modulator (CREM) gene, transcribed from promoters $\mathrm{P} 3$ and $\mathrm{P} 4$, are highly testis-specific in primates. Molecular Human Reproduction 8 965-976.

Gendron RL, Paradis H, Hsieh-Li HM, Lee DW, Potter SS \& Markoff E 1997 Abnormal uterine stromal and glandular function associated with maternal reproductive defects in Hoxa-11 null mice. Biology of Reproduction 56 1097-1105.

Ghosh AK, Lacson R, Liu P, Cichy SB, Danilkovich A, Guo S \& Unterman TG 2001 A nucleoprotein complex containing CCAAT/enhancer-binding protein $\beta$ interacts with an insulin response sequence in the insulin-like growth factor-binding protein-1 gene and contributes to insulin-regulated gene expression. Journal of Biological Chemistry 276 8507-8515.

Giangrande PH, Kimbrel EA, Edwards DP \& McDonnell DP 2000 The opposing transcriptional activities of the two isoforms of the human progesterone receptor are due to differential cofactor binding. Molecular and Cellular Biology 20 3102-3115.

Gilchrist RL, Ryu K-S, Ji I \& Ji TH 1996 The luteinizing hormone/chorionic gonadotropin receptor has distinct transmembrane conductors for CAMP and inositol phosphate signals. Journal of Biological Chemistry 271 19283-19287.

Gravanis A, Stournaras C \& Margioris AN 1999 Paracrinology of endometrial neuropeptides: corticotropin-releasing hormone and opioids. Seminars in Reproductive Endocrinology 17 29-38.

Gregory CW, Wilson EM, Apparao KB, Lininger RA, Meyer WR, Kowalik A, Fritz MA \& Lessey BA 2002 Steroid receptor 
coactivator expression throughout the menstrual cycle in normal and abnormal endometrium. Journal of Clinical Endocrinology and Metabolism 87 2960-2966.

Guo S, Rena G, Cichy S, He X, Cohen P \& Unterman T 1999 Phosphorylation of serine 256 by protein kinase B disrupts transactivation by FKHR and mediates effects of insulin on insulin-like growth factor-binding protein-1 promoter activity through a conserved insulin response sequence. Journal of Biological Chemistry 274 17184-17192.

Hall RA, Premont RT \& Lefkowitz RJ 1999 Heptahelical receptor signaling: beyond the $\mathrm{G}$ protein paradigm. Journal of Cell Biology 145 927-932.

Han SW, Lei ZM \& Rao CV 1997 Homologous down-regulation of luteinizing hormone chorionic gonadotropin receptors by increasing the degradation of receptor transcripts in human uterine endometrial stromal cells. Biology of Reproduction 57 158-164.

Herrlich A, Kühn B, Grosse R, Schmid A, Schultz G \& Gudermann T 1996 Involvement of Gs and Gi proteins in dual coupling of the luteinizing hormone receptor to adenylyl cyclase and phospholipase C. Journal of Biological Chemistry 271 16764-16772.

Hillhouse EW \& Grammatopoulos DK 2002 Role of stress peptides during human pregnancy and labour. Reproduction 124 323-329.

Hochstrasser M 2001 SP-RING for SUMO: new functions bloom for a ubiquitin-like protein. Cell 107 5-8.

Houserman VL, Todd H \& Hertelendy F 1989 Progesterone treatment in vitro enhances prostaglandin $\mathrm{E}$ and forskolin-promoted cyclic AMP production in human endometrial stromal cells. Journal of Reproduction and Fertility 85 195-202.

Hovland AR, Powell RL, Takimoto GS, Tung L \& Horwitz KB 1998 An N-terminal inhibitory function, IF, suppresses transcription by the A-isoform but not the $\mathrm{B}$-isoform of human progesterone receptors. Journal of Biological Chemistry 273 5455-5460.

Hsu SY, Nakabayashi K, Nishi S, Kumagai J, Kudo M, Sherwood OD \& Hsueh AJ 2002 Activation of orphan receptors by the hormone relaxin. Science 295 671-674.

Irwin JC, Kirk D, King RJB, Quigley MM \& Gwatkin RBL 1989 Hormonal regulation of human endometrial stromal cells in culture: an in vitro model for decidualization. Fertility and Sterility $\mathbf{5 2}$ 761-768.

Ivell R 2002 This hormone has been relaxin' too long! Science 295 637-638.

Janknecht R \& Hunter T 1996 Transcriptional control: versatile molecular glue. Current Biology 6 951-954.

Jikihara H \& Handwerger S 1994 Tumor necrosis factor- $\alpha$ inhibits the synthesis and release of human decidual prolactin. Endocrinology 134 353-357.

Kaestner KH, Knochel W \& Martinez DE 2000 Unified nomenclature for the winged helix/forkhead transcription factors. Genes and Development 14 142-146.

Kamei Y, Xu L, Heinzel T, Torchia J, Kurokawa R, Gloss B, Lin SC, Heyman RA, Rose DW, Glass CK \& Rosenfeld MG 1996 A CBP integrator complex mediates transcriptional activation and AP-1 inhibition by nuclear receptors. Cell 85 403-414.

Kariya M, Kanzaki H, Takakura K, Imai K, Okamoto N, Emi N, Kariya Y \& Mori T 1991 Interleukin-1 inhibits in vitro decidualization of human endometrial stromal cells. Journal of Clinical Endocrinology and Metabolism 73 1170-1174.

Kasahara K, Takakura K, Takebayashi K, Kimura F, Nakanishi K \& Noda Y 2001 The role of human chorionic gonadotropin on decidualization of endometrial stromal cells in vitro. Journal of Clinical Endocrinology and Metabolism 86 1281-1286.

Kastner P, Krust A, Turcotte B, Stropp U, Tora L, Gronemeyer H \& Chambon P 1990 Two distinct estrogen-regulated promoters generate transcripts encoding the two functionally different human progesterone receptor forms A and B. EMBO Journal 9 1603-1614.

Kim JJ, Jaffe RC \& Fazleabas AT 1998 Comparative studies on the in vitro decidualization process in the baboon (Papio anubis) and human. Biology of Reproduction 59 160-168.
Kim JJ, Taylor HS, Akbas GE, Foucher I, Trembleau A, Jaffe RC, Fazleabas AT \& Unterman TG 2003 Regulation of insulin-like growth factor binding protein-1 promoter activity by FKHR and HOXA10 in primate endometrial cells. Biology of Reproduction $\mathbf{6 8}$ 24-30.

King A 2000 Uterine leukocytes and decidualization. Human Reproduction Update 6 28-36.

Kops GJ, Dansen TB, Polderman PE, Saarloos I, Wirtz KW, Coffer PJ, Huang TT, Bos JL, Medema RH \& Burgering BM 2002a Forkhead transcription factor FOXO3a protects quiescent cells from oxidative stress. Nature 419 316-321.

Kops GJ, Medema RH, Glassford J, Essers MA, Dijkers PF, Coffer PJ, Lam EW \& Burgering BM $2002 b$ Control of cell cycle exit and entry by protein kinase B-regulated forkhead transcription factors. Molecular and Cellular Biology 22 2025-2036.

Kubota T, Taguchi M, Kobayashi K, Masuda M \& Aso T 1997 Relationship between the release of prolactin and endothelin-1 in human decidualized endometrial cells. European Journal of Endocrinology 137 200-204.

Kumar S, Li Q, Dua A, Ying YK, Bagchi MK \& Bagchi IC 2001 Messenger ribonucleic acid encoding interferon-inducible guanylate binding protein 1 is induced in human endometrium within the putative window of implantation. Journal of Clinical Endocrinology and Metabolism 86 2420-2427.

Lachapelle MH, Miron P, Hemmings R \& Roy DC 1996 Endometrial T, B, and NK cells in patients with recurrent spontaneous abortion. Altered profile and pregnancy outcome. Journal of Immunology 156 4027-4034.

Lane B, Oxberry W, Mazella J \& Tseng L 1994 Decidualization of human endometrial stromal cells in vitro: effects of progestin and relaxin on the ultrastructure and production of decidual secretory proteins. Human Reproduction 9 259-266.

Lange CA, Richer JK, Shen T \& Horwitz KB 1998 Convergence of progesterone and epidermal growth factor signaling in breast cancer. Potentiation of mitogen-activated protein kinase pathways. Journal of Biological Chemistry 273 31308-31316.

Lange CA, Shen T \& Horwitz KB 2000 Phosphorylation of human progesterone receptors at serine-294 by mitogen-activated protein kinase signals their degradation by the $26 \mathrm{~S}$ proteasome. PNAS 97 1032-1037.

Li TC, Iqbal T, Anstie B, Gillham J, Amer S, Wood K \& Laird S 2002 An analysis of the pattern of pregnancy loss in women with recurrent miscarriage. Fertility and Sterility 78 1100-1106.

Lim H, Paria BC, Das SK, Dinchuk JE, Langenbach R, Trzaskos JM \& Dey SK 1997 Multiple female reproductive failures in cyclooxygenase 2-deficient mice. Cell 91 197-208.

Lim KJ, Odukoya OA, Ajjan RA, Li TC, Weetman AP \& Cooke ID 2000 The role of T-helper cytokines in human reproduction. Fertility and Sterility 73 136-142.

Lockwood CJ, Nemerson Y, Guller S, Krikun G, Alvarez M, Hausknecht V, Gurpide E \& Schatz F 1993 Progestational regulation of human endometrial stromal cell tissue factor expression during decidualization. Journal of Clinical Endocrinology and Metabolism 76 231-236.

Luscombe NM, Austin SE, Berman HM \& Thornton JM 2000 An overview of the structures of protein-DNA complexes. Genome Biology 1 reviews 001·1-001·37.

Lydon JP, DeMayo FJ, Funk CR, Mani SK, Hughes AR, Montgomery CA Jr, Shyamala G, Conneely OM \& O'Malley BW 1995 Mice lacking progesterone receptor exhibit pleiotropic reproductive abnormalities. Genes and Development 9 2266-2278.

Ma L, Benson GV, Lim H, Dey SK \& Maas RL 1998 Abdominal B (AbdB) Hoxa genes: regulation in adult uterus by estrogen and progesterone and repression in mullerian duct by the synthetic estrogen diethylstilbestrol (DES). Developmental Biology 197 141-154.

Mak IYH, Brosens JJ, Christian M, Hills FA, Chamley L, Regan L \& White JO 2002 Regulated expression of signal transducer and 
activator of transcription, Stat5, and its enhancement of PRL expression in human endometrial stromal cells in vitro. Journal of Clinical Endocrinology and Metabolism 87 2581-2588.

Maller JL 2001 The elusive progesterone receptor in Xenopus oocytes. PNAS 98 8-10.

Marinissen MJ \& Gutkind JS 2001 G-protein-coupled receptors and signaling networks: emerging paradigms. Trends in Pharmacological Sciences 22 368-376.

Maruyama T, Yoshimura Y, Yodoi J \& Sabe H 1999 Activation of c-Src kinase is associated with in vitro decidualization of human endometrial stromal cells. Endocrinology 140 2632-2636.

Mayr B \& Montminy M 2001 Transcriptional regulation by the phosphorylation-dependent factor CREB. Nature Reviews Molecular Cell Biology 2 599-609.

Medema RH, Kops GJ, Bos JL \& Burgering BM 2000 AFX-like Forkhead transcription factors mediate cell-cycle regulation by Ras and PKB through p27 kip1. Nature 404 782-787.

Mehats C, Andersen CB, Filopanti M, Jin SL \& Conti M 2002 Cyclic nucleotide phosphodiesterases and their role in endocrine cell signaling. Trends in Endocrinology and Metabolism 13 29-35.

Mei FC, Qiao J, Tsygankova OM, Meinkoth JL, Quilliam LA \& Cheng X 2002 Differential signaling of cyclic AMP: opposing effects of exchange protein directly activated by cyclic AMP and cAMP-dependent protein kinase on protein kinase B activation. Journal of Biological Chemistry 277 11497-11504.

Melchior F 2000 SUMO - nonclassical ubiquitin. Annual Reviews of Cell and Developmental Biology 16 591-626.

Meyer ME, Quirin-Stricker C, Lerouge T, Bocquel MT \& Gronemeyer H 1992 A limiting factor mediates the differential activation of promoters by the human progesterone receptor isoforms. Journal of Biological Chemistry 267 10882-10887.

Milne SA, Perchick GB, Boddy SC \& Jabbour HN 2001 Expression, localization, and signaling of $\mathrm{PGE}_{2}$ and $\mathrm{EP} 2 / \mathrm{EP} 4$ receptors in human nonpregnant endometrium across the menstrual cycle. Journal of Clinical Endocrinology and Metabolism 86 4453-4459.

Mink S, Haenig B \& Klempnauer KH 1997 Interaction and functional collaboration of p300 and C/EBP $\beta$. Molecular and Cellular Biology 17 6609-6617.

Molina CA, Foulkes NS, Lalli E \& Sassone-Corsi P 1993 Inducibility and negative autoregulation of CREM: an alternative promoter directs the expression of ICER, an early response repressor. Cell $\mathbf{7 5}$ 875-886.

Montminy M 1997 Transcriptional activation. Something new to hang your HAT on. Nature 387 654-655.

Mote PA, Balleine RL, McGowan EM \& Clarke CL 1999 Colocalization of progesterone receptors $\mathrm{A}$ and $\mathrm{B}$ by dual immunofluorescent histochemistry in human endometrium during the menstrual cycle. Journal of Clinical Endocrinology and Metabolism 84 2963-2971.

Mulac-Jericevic B, Mullinax RA, DeMayo FJ, Lydon LP \& Conneely OM 2000 Subgroup of reproductive functions of progesterone mediated by progesterone receptor-B isoform. Science $\mathbf{2 8 9}$ $1751-1754$.

Muller S, Hoege C, Pyrowolakis G \& Jentsch S 2001 SUMO, ubiquitin's mysterious cousin. Nature Reviews Molecular Cell Biology $2202-210$.

Mutter GL, Lin MC, Fitzgerald JT, Kum JB \& Eng C 2000 Changes in endometrial PTEN expression throughout the human menstrual cycle. Journal of Clinical Endocrinology and Metabolism 85 2334-2338.

Narumiya S \& FitzGerald GA 2001 Genetic and pharmacological analysis of prostanoid receptor function. Journal of Clinical Investigation 108 25-30.

Narumiya S, Sugimoto Y \& Ushikubi F 1999 Prostanoid receptors: structures, properties, and functions. Physiological Reviews $\mathbf{7 9}$ 1193-1226.

Nazareth LV \& Weigel NL 1996 Activation of the human androgen receptor through a protein kinase A signaling pathway. Journal of Biological Chemistry 271 19900-19907.
Nemansky M, Moy E, Lyons CD, Yu I \& Blithe DL 1998 Human endometrial stromal cells generate uncombined $\alpha$-subunit from human chorionic gonadotropin, which can synergize with progesterone to induce decidualization. Journal of Clinical Endocrinology and Metabolism 83 575-581.

Ogryzko VV, Schiltz RL, Russanova V, Howard BH \& Nakatani Y 1996 The transcriptional coactivators p300 and CBP are histone acetyltransferases. Cell 87 953-959.

Olayioye MA, Beuvink I, Horsch K, Daly JM \& Hynes NE 1999 ErbB receptor-induced activation of stat transcription factors is mediated by Src tyrosine kinases. Journal of Biological Chemistry 274 17209-17218.

Oliver C, Cowdrey N, Abadia-Molina AC \& Olivares EG 1999a Antigen phenotype of cultured decidual stromal cells of human term decidua. Journal of Reproductive Immunology 45 19-30.

Oliver C, Montes MJ, Galindo JA, Ruiz C \& Olivares EG 19996 Human decidual stromal cells express $\alpha$-smooth muscle actin and show ultrastructural similarities with myofibroblasts. Human Reproduction 14 1599-1605.

Palejawa S, Tseng L, Wojtczuk A, Weiss G \& Goldsmith LT 2002 Relaxin gene and protein expression and its regulation of procollagenase and vascular endothelial growth factor in human endometrial cells. Biology of Reproduction 66 1743-1748.

Pihoker C, Feeney RJ, Su JL \& Handwerger S 1991 Lipocortin-I inhibits the synthesis and release of prolactin from human decidual cells: evidence for autocrine/paracrine regulation by lipocortin-I. Endocrinology 128 1123-1128.

Pohnke Y, Kempf R \& Gellersen B 1999 CCAAT/enhancer-binding proteins are mediators in the protein kinase A-dependent activation of the decidual prolactin gene. Journal of Biological Chemistry 274 24808-24818.

Popovici RM, Kao LC \& Giudice LC 2000 Discovery of new inducible genes in in vitro decidualized human endometrial stromal cells using microarray technology. Endocrinology 141 3510-3513.

Ramji DP \& Foka P 2002 CCAAT/enhancer-binding proteins: structure, function and regulation. Biochemical Journal 365 561-575.

Ramsey EM, Houston ML \& Harris JW 1976 Interactions of the trophoblast and maternal tissues in three closely related primate species. American Journal of Obstetrics and Gynecology 124 647-652.

Rena G, Guo S, Cichy SC, Unterman TG \& Cohen P 1999 Phosphorylation of the transcription factor forkhead family member FKHR by protein kinase B. Journal of Biological Chemistry 274 17179-17183.

Richards JS 2001 New signaling pathways for hormones and cyclic adenosine $3^{\prime}, 5^{\prime}$-monophosphate action in endocrine cells. Molecular Endocrinology 15 209-218.

Richer JK, Lange CA, Manning NG, Owen G, Powell R \& Horwitz KB 1998 Convergence of progesterone with growth factor and cytokine signaling in breast cancer. Progesterone receptors regulate signal transducers and activators of transcription expression and activity. Journal of Biological Chemistry 273 31317-31326.

Richer JK, Jacobsen BM, Manning NG, Abel MG, Wolf DM \& Horwitz KB 2002 Differential gene regulation by the two progesterone receptor isoforms in human breast cancer cells. Journal of Biological Chemistry 277 5209-5218.

Rider V 2002 Progesterone and the control of uterine cell proliferation and differentiation. Frontiers in Bioscience 7 d1545-1555.

Robb L, Li R, Hartley L, Nandurkar HH, Koentgen F \& Begley CG 1998 Infertility in female mice lacking the receptor for interleukin 11 is due to a defective uterine response to implantation. Nature Medicine 4 303-308.

Robinson GW, Johnson PF, Hennighausen L \& Sterneck E 1998 The $\mathrm{C} / \mathrm{EBP} \beta$ transcription factor regulates epithelial cell proliferation and differentiation in the mammary gland. Genes and Development 12 1907-1916.

Rowan BG, Garrison N, Weigel NL \& O'Malley BW 2000a 8-Bromo-cyclic AMP induces phosphorylation of two sites in SRC-1 that facilitate ligand-independent activation of the chicken 
progesterone receptor and are critical for functional cooperation between SRC-1 and CREB binding protein. Molecular and Cellular Biology 20 8720-8730.

Rowan BG, Weigel NL \& O'Malley BW $2000 b$ Phosphorylation of steroid receptor coactivator-1. Identification of the phosphorylation sites and phosphorylation through the mitogen-activated protein kinase pathway. Journal of Biological Chemistry 275 4475-4483.

Sartorius CA, Groshong SD, Miller LA, Powell RL, Tung L, Takimoto GS \& Horwitz KB 1994a New T47D breast cancer cell lines for the independent study of progesterone B- and A-receptors: only antiprogestin-occupied B-receptors are switched to transcriptional agonists by cAMP. Cancer Research 54 3868-3877.

Sartorius CA, Melville MY, Hovland AR, Tung L, Takimoto GS \& Horwitz KB 1994b A third transactivation function (AF3) of human progesterone receptors located in the unique $\mathrm{N}$-terminal segment of the B-isoform. Molecular Endocrinology 8 1347-1360.

Schindler C \& Darnell JE Jr 1995 Transcriptional responses to polypeptide ligands: the JAK-STAT pathway. Annual Reviews of Biochemistry 64 621-651.

Schuur ER, Loktev AV, Sharma M, Sun Z, Roth RA \& Weigel RJ 2001 Ligand-dependent interaction of estrogen receptor- $\alpha$ with members of the forkhead transcription factor family. Journal of Biological Chemistry 276 33554-33560.

Scott BA, Avidan MS \& Crowder CM 2002 Regulation of hypoxic death in C. elegans by the insulin/IGF receptor homolog DAF-2. Science $2962388-2391$.

Scott JR \& Pattison N 2000 Human chorionic gonadotrophin for recurrent miscarriage. Cochrane Database of Systematic Reviews CD000101

Seagroves TN, Krnacik S, Raught B, Gay J, Burgess-Beusse B, Darlington GJ \& Rosen JM $1998 \mathrm{C} / \mathrm{EBP} \beta$, but not C/EBP $\alpha$, is essential for ductal morphogenesis, lobuloalveolar proliferation, and functional differentiation in the mouse mammary gland. Genes and Development 12 1917-1928.

Shen T, Horwitz KB \& Lange CA 2001 Transcriptional hyperactivity of human progesterone receptors is coupled to their liganddependent down-regulation by mitogen-activated protein kinase-dependent phosphorylation of serine 294. Molecular and Cellular Biology 21 6122-6131.

Skålhegg BS \& Taskén K 2000 Specificity in the cAMP/PKA signaling pathway, differential expression, regulation, and subcellular localization of subunits of PKA. Frontiers in Bioscience 5 D678-D693.

Smith CL, Onate SA, Tsai MJ \& O'Malley BW 1996 CREB binding protein acts synergistically with steroid receptor coactivator-1 to enhance steroid receptor-dependent transcription. PNAS $\mathbf{9 3}$ 8884-8888.

Sterneck E, Tessarollo L \& Johnson PF 1997 An essential role for $\mathrm{C} / \mathrm{EBP} \beta$ in female reproduction. Genes and Development 11 2153-2162.

Stewart CL \& Cullinan EB 1997 Preimplantation development of the mammalian embryo and its regulation by growth factors. Developmental Genetics 21 91-101.

Sudo S, Kumagai J, Nishi S, Layfield S, Ferraro T, Bathgate RAD \& Hsueh AJW $2002 \mathrm{H} 3$ relaxin is a specific ligand for LGR7 and activates the receptor by interacting with both the ectodomain and the exoloop 2. Journal of Biological Chemistry 278 7855-7862.

Tabanelli S, Tang B \& Gurpide E 1992 In vitro decidualization of human endometrial stromal cells. Journal of Steroid Biochemistry and Molecular Biology 42 337-344.

Tanaka N, Miyazaki K, Tashiro H, Mizutani H \& Okamura H 1993 Changes in adenylyl cyclase activity in human endometrium during the menstrual cycle and in human decidua during pregnancy. Journal of Reproduction and Fertility 97 33-39.

Tang B \& Gurpide E 1993 Direct effect of gonadotropins on decidualization of human endometrial stromal cells. Journal of Steroid Biochemistry and Molecular Biology 47 115-121.

Taskén K, Skålhegg BS, Taskén KA, Solberg R, Knutsen HK, Levy FO, Sandberg M, Ørstavik S, Larsen T, Johansen AK et al. 1997
Structure, function, and regulation of human cAMP-dependent protein kinases. Advances in Second Messenger Phosphoprotein Research 31 191-204.

Telgmann R \& Gellersen B 1998 Marker genes of decidualization: activation of the decidual prolactin gene. Human Reproduction Update 4 472-479.

Telgmann R, Maronde E, Taskén K \& Gellersen B 1997 Activated protein kinase $\mathrm{A}$ is required for differentiation-dependent transcription of the decidual prolactin gene in human endometrial stromal cells. Endocrinology 138 929-937.

Tseng L, Gao JG, Chen R, Zhu HH, Mazella J \& Powell DR 1992 Effect of progestin, antiprogestin, and relaxin on the accumulation of prolactin and insulin-like growth factor-binding protein-1 messenger ribonucleic acid in human endometrial stromal cells. Biology of Reproduction 47 441-450.

Tung L, Mohamed MK, Hoeffler JP, Takimoto GS \& Horwitz KB 1993 Antagonist-occupied human progesterone B-receptors activate transcription without binding to progesterone response elements and are dominantly inhibited by A-receptors. Molecular Endocrinology 7 $1256-1265$

Vegeto E, Shahbaz MM, Wen DX, Goldman ME, O'Malley BW \& McDonnell DP 1993 Human progesterone receptor A form is a cell- and promoter-specific repressor of human progesterone receptor B function. Molecular Endocrinology 7 1244-1255.

Wagner BL, Norris JD, Knotts TA, Weigel NL \& McDonnell DP 1998 The nuclear corepressors NCoR and SMRT are key regulators of both ligand- and 8-bromo-cyclic AMP-dependent transcriptional activity of the human progesterone receptor. Molecular and Cellular Biology 18 1369-1378.

Walker WH \& Habener JF 1996 Role of transcription factors CREB and CREM in cAMP-regulated transcription during spermatogenesis. Trends in Endocrinology and Metabolism 7 133-138.

Wang H, Critchley HOD, Kelly RW, Shen D \& Baird DT 1998 Progesterone receptor subtype B is differentially regulated in human endometrial stroma. Molecular Human Reproduction 4 407-412.

Wardell SE, Boonyaratanakornkit V, Adelman JS, Aronheim A \& Edwards DP 2002 Jun dimerization protein 2 functions as a progesterone receptor $\mathrm{N}$-terminal domain coactivator. Molecular and Cellular Biology 22 5451-5466.

Wen DX, Xu YF, Mais DE, Goldman ME \& McDonnell DP 1994 The $\mathrm{A}$ and $\mathrm{B}$ isoforms of the human progesterone receptor operate through distinct signaling pathways within target cells. Molecular and Cellular Biology 14 8356-8364.

Wieser F, Schneeberger C, Hudelist G, Singer C, Kurz C, Nagele F, Gruber C, Huber JC \& Tschugguel W 2002 Endometrial nuclear receptor co-factors SRC-1 and $\mathrm{N}-\mathrm{CoR}$ are increased in human endometrium during menstruation. Molecular Human Reproduction $\mathbf{8}$ 644-650.

Wolkersdörfer GW, Bornstein SR, Hilbers U, Zimmermann G, Biesold C, Lehmann M \& Alexander H 1998 The presence of chorionic gonadotrophin $\beta$ subunit in normal cyclic human endometrium. Molecular Human Reproduction 4 179-184.

Xu J, Qiu Y, DeMayo FJ, Tsai SY, Tsai MJ \& O’Malley BW 1998 Partial hormone resistance in mice with disruption of the steroid receptor coactivator-1 (SRC-1) gene. Science 279 1922-1925.

Yamamoto Y, Maruyama T, Sakai N, Sakurai R, Shimizu A, Hatamani T, Masuda H, Uchida H, Sabe H \& Yoshimura Y 2002 Expression and subcellular distribution of the active form of $\mathrm{c}-\mathrm{Src}$ tyrosine kinase in differentiating human endometrial stromal cells. Molecular Human Reproduction 8 1117-1124.

Zhang Q, Liu SH, Erikson M, Lewis M \& Unemori E 2002 Relaxin activates the MAP kinase pathway in human endometrial stromal cells. Journal of Cellular Biochemistry 85 536-544.

Zhao HH, Herrera RE, Coronado-Heinsohn E, Yang MC, Ludes-Meyers JH, Seybold-Tilson KJ, Nawaz Z, Yee D, Barr FG, Diab SG et al. 2001 Forkhead homologue in rhabdomyosarcoma 
functions as a bifunctional nuclear receptor-interacting protein with both coactivator and corepressor functions. Journal of Biological Chemistry $27627907-27912$.

Zhu Y, Bond J \& Thomas P 2003a Identification, classification, and partial characterization of genes in humans and other vertebrates homologous to a fish membrane progestin receptor. PNAS $\mathbf{1 0 0}$ 2237-2242.

Zhu Y, Rice CD, Pang Y, Pace M \& Thomas P 2003b Cloning, expression, and characterization of a membrane progestin receptor and evidence that it is an intermediary in meiotic maturation of fish oocytes. PNAS 100 2231-2236.

de Ziegler D, Fanchin R, de Moustier B \& Bulletti C 1998 The hormonal control of endometrial receptivity: estrogen (E2) and progesterone. Journal of Reproductive Immunology 39 149-166.

Received in final form 28 May 2003

Accepted 29 May 2003 